\title{
Responses of downy brome to nitrogen and water
}

\author{
STEVEN O. LINK, HARVEY BOLTON, JR., MICHAEL E. THIEDE, AND WILLIAM H. \\ RICKARD
}

\begin{abstract}
Authors are respectively, senior research scientist, senior research scientist, research scientist, and staff scientist, Earth and Emironmental Sciences Center, Pacific Nonthwest Labaraton;, Richland, Wash. 99352.
\end{abstract}

\begin{abstract}
Downy brome (Bromus tectorum $\mathrm{L}$.) is an alien grass that dominates disturbed ground in shrub-steppe ecosystems of the western United States. Responses of downy brome to added nitrogen and water were evaluated using intact soil cores obtained from an old field. Gas exchange data were gathered at the leaf and canopy scales. Stomatal conductance and net photosynthesis rates were greater at the leaf scale than at the canopy scale, decreased with time from germination, and were weakly affected by treatments. Water-use efficiency was weakly related to time from germination and treatments. Biomass was greater in the nitrogen-plus-water (7.4 g) treatment, compared with water (3.6 $\mathrm{g}$ ), nitrogen ( $4.5 \mathrm{~g}$ ), and control ( $3.3 \mathrm{~g})$ treatments. The leaf-area index varied like biomass at the end of the experiment. Shoot nitrogen was the same in the nitrogen $(2.5 \%)$ and nitrogen-pluswater $(2.5 \%)$ treatments, nearly twice the level in the control $(1.5 \%)$ and water $(1.3 \%)$ treatments. Nitrogen-use efficiency was highest in the control (67) and water (80) treatments and lowest in the nitrogen (41) and nitrogen-plus-water (43) treatments. The most significant conclusion of this work is that gas exchange was strongly related to the time from germination and little affected by water and nitrogen while growth characters were strongly affected only when water and nitrogen were added together.
\end{abstract}

Key words: Bromus tectorum L., biomass, photosynthesis, conductance, water-use efficiency, nitrogen-use efficiency

Plant resource use strategies in resource-limited ecosystems largely determine species composition (Tilman 1987). Species most efficient in nitrogen use dominated when nitrogen was most limiting in Minnesota (Tilman 1986, 1987). An understanding of resource-use strategies is relatively simple when only one soil resource is limiting, as in the above-mentioned studies in Minnesota. When more than one resource is limiting, such as water and nitrogen, as in the shrub-steppe, resource-use strategies become more difficult to understand.

It is important to understand how various species use limited resources, especially when invasive species such as downy brome

Research was funded by the U.S. Department of Energy under Contract DEAC06-76RLO 1830.

Authors wish to thank J. Bernhard, J. L. Dow ns. M. J. Harris, and D. Lettau for technical support. Discussions with Drs. L. E Rogers and G. W. Gee were invaluable. We thank Drs. A. Hoffmann and J $\mathbf{M}$ Thomas for advise on statistical analyses. The suggestions of an anonymous reviewer improved the manuscript.

Manuscript accepted 17 Oct. 1994.
(Bromus tectorum L.) have come to dominate resource-limited rangelands in the western United States (Klemmedson and Smith 1964, Mack 1981, Billings 1990). Downy brome shoot and root biomass increased with additional nitrogen in the field (Hulbert 1955). Biomass production was significantly related to stored soil moisture (Cline and Rickard 1973, Uresk et al. 1979). Cline and Rickard (1973) found that nitrogen was more limiting than soil water for shoot biomass production over several years of observation in the field. Past studies have investigated the response of downy brome production to nitrogen and water, separately. There have been no studies investigating the interaction of nitrogen and water on the physiology and growth of downy brome.

The purpose of this study was to investigate the growth and gas exchange response of downy brome to separate and combined additions of nitrogen and water. We examined growth and gas exchange responses to water and nitrogen as a function of the time from germination. Gas exchange observations were taken at leaf and canopy scales.

\section{Materials and Methods}

\section{Study Area}

The study site is an old field on the U.S. Department of Energy's Arid Lands Ecology Reserve of the Hanford Site in south-central Washington $\left(119^{\circ} 43^{\prime} \mathrm{W}, 46^{\circ} 28^{\prime} \mathrm{N}, 323\right.$ m.a.s.l.). The average annual precipitation is $16 \mathrm{~cm}$, occurring mostly in the autumn and winter (Stone et al. 1983). The soil is classified as a Warden silt loam (Hajek 1966), and is more than $1 \mathrm{~m}$ deep. The site was used to grow wheat until 1943-44, when it was abandoned. A few stray livestock were present until 1967. It continues to be dominated by downy brome, mixed with tumble mustard (Sisymbrium altissimum L.) and several other alien annual forbs. A few clumps of native Sandberg's bluegrass (Poa sandbergii Vasey) have become established (Rickard and Vaughan 1988). The surrounding vegetation is sagebrush-bluebunch wheatgrass (Artemisia tridentata ssp.tridentata Nutt-Pseudoroegneria spicata (Pursh) A. Love) habitat as described by Daubenmire (1970).

\section{Leaf Gas Exchange Experiment}

The top $15 \mathrm{~cm}$ of soil was collected from the old field and completely mixed for use in the laboratory. The soil contained 3.2 ppm NO${ }_{3}, 5 \mathrm{ppm} \mathrm{S}, 11 \mathrm{ppm} \mathrm{P}$, and $361 \mathrm{ppm} \mathrm{K}$. Ten 3.8-liter pots were lined with plastic, filled with soil, brought to $20 \%$ soil moisture with distilled water, and seeded. Seeds were planted in 10 
locations around the pot, with 5 seeds per hole. One week after planting, a nitrogen treatment was established by adding $0.9 \mathrm{~g}$ of $\mathrm{NH}_{4} \mathrm{NO}_{3}$ in solution to each of 5 pots. Pots were well watered during the experiment. There were 5 replicate pots in each of the nitrogen-plus-water and water treatments. Plants were grown in environmentally controlled chambers, with a light period of 16 hours and a night period of $S$ hours. Day and night temperatures were 24 and $15^{\circ} \mathrm{C}$, respectively. Photosynthetically active radiation, measured with a LI-COR 190SB Quantum sensor (Li-Cor Inc.), during the day, was $350 \mu \mathrm{mol}$ photons $\mathrm{m}^{-2} \mathrm{~s}^{-1}$.

Gas-exchange data were collected at steady-state with a null balance system (Data Design Group, La Jolla, CA). This system controls the $\mathrm{CO}_{2}$ and water vapor concentration and temperature inside a cuvette that can accommodate several leaves. The experiment was conducted under steady-state cuvette conditions of 340 ppm $\mathrm{CO}_{2}$ in air $\left(21 \% \mathrm{O}_{2}\right)$, leaf temperature of $28^{\circ} \mathrm{C}$, vapor pressure gradient of $2.5 \mathrm{kPa}$, and a photosynthetically active radiation level of $550 \mu \mathrm{mol}$ photons $\mathrm{m}^{-2} \mathrm{~s}^{-1}$. Data were collected 21,35 , and 56 days after germination on several leaf tips (approximately $7 \mathrm{~cm}$ long) at the top of the canopy. Plants remained in a vegetative state without going to flower throughout the experiment. Leaf area is expressed as single-sided values, and was determined immediately after gas exchange analyses using a Li-Cor 3100 leaf-area meter.

\section{Canopy Gas Exchange Experiment}

Twenty intact soil cores (microcosms) were taken from the old field on 4 Nov. 1988. The microcosms were encased in polyvinyl chloride tubes that were $40 \mathrm{~cm}$ deep and $25 \mathrm{~cm}$ in diameter. The tubes were pounded into the soil to extract the microcosms and the bottoms were taped shut. The microcosms were randomly placed in a growth chamber with a light period of 12 hours, and periodically rearranged. Microcosms were periodically rearranged to minimize variation associated with light patterns inside the growth chamber. Photosynthetically active radiation in the growth chamber averaged $265 \mu \mathrm{mol}$ photons $\mathrm{m}^{-2} \mathrm{~s}^{-1}$. Air temperature was maintained at $20^{\circ} \mathrm{C}$ in the light and $15^{\circ} \mathrm{C}$ in the dark. Downy brome seeds germinated naturally.

Four treatments were created, each using 5 microcosms. Treatments were the control ( 1 liter distilled water added at the beginning of the experiment), nitrogen (soil enriched with $10 \mathrm{~g} \mathrm{~N}$ $\mathrm{m}^{-2}$ added as $\mathrm{NH}_{4} \mathrm{NO}_{3}$ fertilizer and 1 liter distilled water added at the beginning of the experiment), water ( 1 liter distilled water added biweekly), and nitrogen-plus-water (soil enriched with 10 $\mathrm{g} \mathrm{N} \mathrm{m}^{-2}$ added as $\mathrm{NH}_{4} \mathrm{NO}_{3}$ fertilizer and 1 liter distilled water added biweekly). One liter of water saturated the microcosms, with the excess draining from the bottom.

The gas exchange system is an open one similar to that of Caldwell et al. (1981, 1983), but has improved flow control and vapor pressure measurement sensors. Carbon dioxide concentrations were measured with an Analytical Development Co. 225 MKIII infrared gas analyzer. Water vapor concentrations entering and leaving the gas exchange chamber were measured with DEW-10 (General Eastern) dew-point hygrometers. Dew-point temperature was measured with platinum resistance thermometers. Other temperatures, including those of leaf, chamber air, heat exchanger fin, and air in lines just ahead of the dew-point hygrometers were measured with fine-wire, copper-constantin thermocouples. Average canopy temperature was measured with 4 thin-wire thermocouples randomly distributed in the canopy and placed in leaf mesophyll tissue. Under gas exchange conditions, light was provided by a $300-\mathrm{W}$ quartz-halogen projection lamp (Field et al. 1989) suspended over the gas exchange chamber.

The gas exchange chamber used for these experiments was a clear, acrylic plastic cylinder (65 cm tall and $30 \mathrm{~cm}$ in diameter), with a flat plastic top and a volume of 46 liters. The chamber was lined with clear fluorinated ethylene propylene (FEP) Teflon ${ }^{\circledR}$ tape to minimize gas absorption by the acrylic plastic (Bloom et al. 1980, Dixon and Grace 1981). The seal between the chamber and the polyvinyl chloride microcosm was made with an aluminum ring having grooves lined with closed-cell foam. The aluminum ring was also covered with Teflon tape. The chamber had an inlet for recirculating air $20 \mathrm{~cm}$ below a similar outlet port, each $6 \mathrm{~cm}$ in diameter. To reduce boundary layer resistance air was circulated with a fan, yielding an average wind speed of $2 \mathrm{~m}$ $\mathrm{s}^{-1}$. An air-conditioning unit was attached to the ports for temperature control. The air-conditioning unit housing was stainless steel and air tight. Temperature was controlled with Peltier chips, heat-exchange fins, and a circulating fan. The heat-exchange fins were made of nickel-plated copper. The heat exchanger and fan motor, located outside the air-conditioning unit, were watercooled.

Air was taken from above the roof of the laboratory by a compressor, and maintained at a pressure of, at least, $276 \mathrm{kPa}$ ahead of 2 air filters and a Tylan (FC-262) mass flow controller. The mass flow controller regulated flow to maintain a constant chamber dew-point temperature. All lines were of copper or Bev-ALine tubing. Sample lines were diverted to measure the dew-point temperature and $\mathrm{CO}_{2}$ concentration of the air going into the chamber. Air was pumped out of the chamber through Bev-ALine tubing for measuring dew-point temperature, and to the infrared gas analyzer for measuring $\mathrm{CO}_{2}$ concentrations.

Soil gas exchange processes were minimized by collecting data only when the soil surface was dry, and maintaining a positive overpressure of 5 to $13 \mathrm{~cm}$ of water (Leafe 1972). In previous experiments with this gas exchange system (Link et al. 1992) on similar downy brome microcosms, we observed a significant contribution of soil gases to system-level gas exchange data. An approximate overprediction of $20 \%$ for canopy transpiration and an underprediction of $30 \%$ for canopy net photosynthesis was observed. These occurred with an overpressure of only $2.5 \mathrm{~cm}$ of water and with few plants (leaf-area index $=0.4$ ). In these conditions, the contribution of soil gases can be significant. In the current experiment, overpressure was higher and leaf-area index was 4 to 10 times greater, except for the initial observations. Thus, the error due to soil-gas exchange is estimated to be less than $10 \%$, except for the initial observations when the plants were small.

Gas exchange measurements were initiated 6 days after germination. All microcosms were observed during a 3-day period; observations were repeated 3 and 5 weeks later. Microcosms were randomly chosen from the growth chamber for observation. Experimental conditions (chamber air temperature of $20^{\circ} \mathrm{C}$, vapor pressure gradient of $1.0 \mathrm{kPa}$, photosynthetically active radiation at the top of the canopy of $925 \mu \mathrm{mol}$ photons $\mathrm{m}^{-2} \mathrm{~s}^{-1}$, and a $\mathrm{CO}_{2}$ concentration in the incoming air stream of $355 \pm 5 \mathrm{ppm}$ ) were held constant for all observations. Average canopy leaf temperature was approximately $1.0^{\circ} \mathrm{C}$ cooler than chamber air temperature. Before each observation, the infrared gas analyzer was calibrated using a primary standard tank of $300 \mathrm{ppm} \mathrm{CO}_{2}$. Steady- 
state conditions were achieved after about $45 \mathrm{~min}$. Gas exchange variables were calculated using the equations of von Caemmerer and Farquhar (1981) as in Caldwell et al. (1983). For example, canopy conductance $\left(\mathrm{g}_{\mathrm{h}}\right)$ was computed as follows:

$$
\mathrm{g}_{\mathrm{h}}=\mathrm{T}_{\mathrm{r}} *\left(1-\left(\mathrm{w}_{\mathrm{l}}+\mathrm{w}_{\mathrm{a}}\right) / 2\right) /\left(\mathrm{w}_{\mathrm{l}}-\mathrm{w}_{\mathrm{a}}\right),
$$

where $T_{r}$ is the canopy transpiration rate, $w_{1}$ is the mole fraction of water in air ( $\mathrm{mol}$ of $\mathrm{H}_{2} \mathrm{O} / \mathrm{mol}$ of air) inside leaves with the assumption that this air is at $100 \%$ relative humidity based on the average canopy temperature, and $\mathrm{w}_{\mathrm{a}}$ is the mole fraction of water in air leaving the chamber.

Leaf and canopy scale gas exchange measurements will differ due to differences in environment and plant characteristics within the 2 systems. Inside the leaf cuvette, leaf temperature, boundary layer resistance, light levels and age of plant material are all homogeneous. Within the canopy system, a more heterogeneous environment is derived from the entire canopy. Temperature was the average of readings collected from 4 randomly located positions. Boundary layer resistance is greater at the bottom than at the top of the canopy and this variation is due to differences in wind speed. Light levels are lower at the bottom of the canopy than at the top. Plant material varies with younger tissue concentrated near the base of the canopy and older tissue near the top. This variation is averaged into gas fluxes at the canopy scale and accounts for some of the differences between canopy and leaf gas exchange rates.

The xylem pressure potential of leaves was measured with a pressure bomb (Scholander et al. 1965). During measurements certain precautions were followed: 1) a humid atmosphere was maintained in the chamber with a damp towel, (2) measurements were made immediately after cutting leaf material, and (3) the chamber was pressurized slowly and consistently for all observations.

Leaf area was estimated nondestructively with each gas exchange observation. Stem heights, stem widths, leaf lengths, and leaf widths were measured on 5 randomly selected individuals in 3 size classes. Then the number of individuals were counted in each size class, and the single-sided leaf area was computed for the canopy.

Biomass and total nitrogen content were measured at the end of the experiment. Oven-dried biomass was determined after plants were dried in a convection oven at $55^{\circ} \mathrm{C}$ for 48 hours. The percentage total nitrogen of shoots was measured by the Colorado State University Soil Testing Lab (Ft. Collins, Colo.) using the micro-Kjeldahl technique. Nitrogen-use efficiency was computed as the ratio of shoot biomass to shoot nitrogen.

\section{Data Analyses}

Data are presented as means \pm 1 standard error of the mean. Repeated-measures analysis of variance was used to test for time, treatment, and time-and-treatment interaction effects. Repeated measures analysis was used because the experimental units were not independent in time.

Linear regression models $\left(\mathrm{Y}=\mathrm{a}+\mathrm{b}\right.$ *time; $\mathrm{Y}=\mathrm{c}+\mathrm{d}^{*}$ time + $\mathrm{e}^{*}$ time $^{2}$ ) were used to estimate parameters over time. To avoid pseudoreplication, because the experimental units were not independent in time, we estimated linear regression parameters for each experimental unit. Mean parameter estimates (b and e) were then computed for differing treatments. Error terms for the mean parameter estimates are reported as the standard error of the mean.

Treatment comparisons within each period were made with Tukey's studentized range test (HSD). Comparisons between leaf and canopy scales in the water and nitrogen-plus-water treatments in comparable time periods were also made with the HSD test. Hypotheses were tested at the $P=0.05$ level.
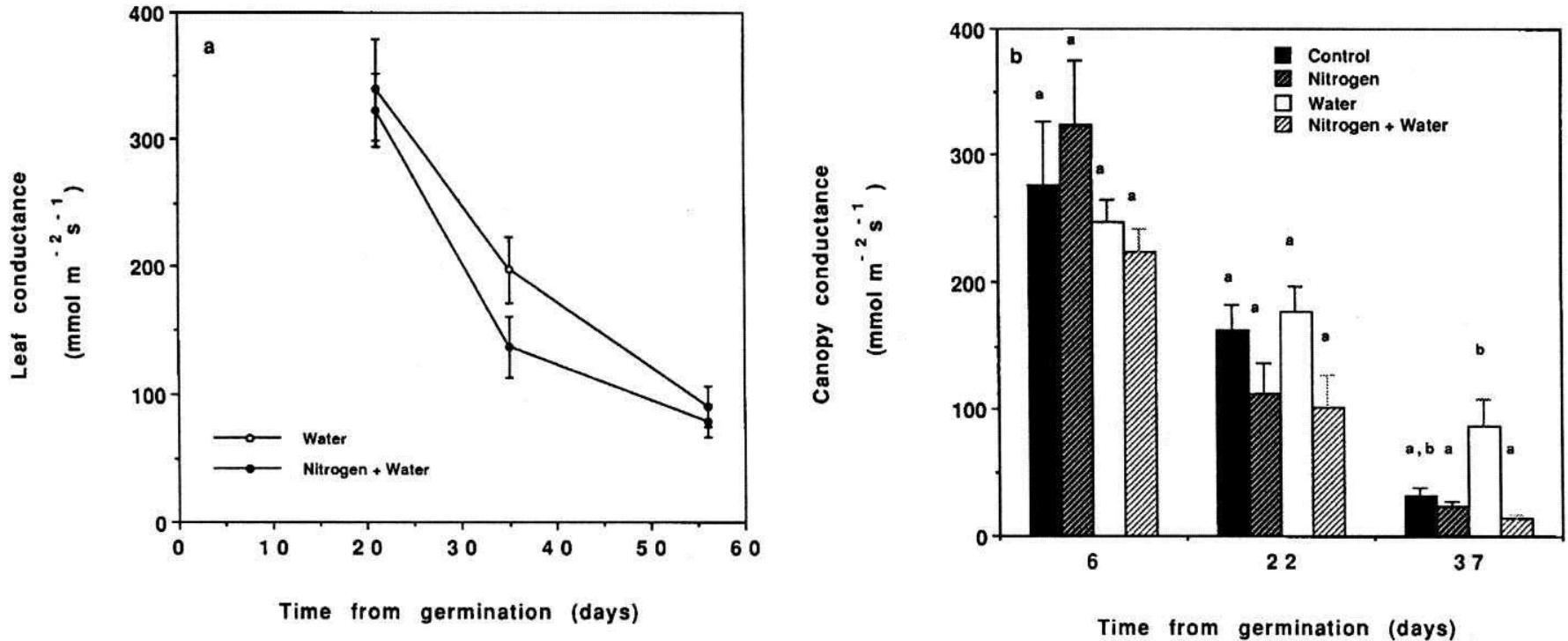

Fig. 1 The effects of the time from germination and water and nitrogen treatments on leaf (a) and canopy (b) conductance of downy brome. Bars are \pm 1 standard error of the mean. Differing letters indicate significant differences $(P=0.05)$ by Tukey's studentized range test (HSD). 


\section{Results}

Leaf conductance decreased with the time from germination ( $p$ $=0.00001)$ and was unaffected by treatments $(p=0.56$ [Fig. 1a]). Canopy conductance was significantly related to the time from germination $(p=0.0001)$, with a significant time by treatment interaction $(p \leq 0.01$ [Fig. 1b]). Canopy conductance decreased with the time from germination. Treatment effects became significant with increasing time from germination at the canopy scale, but not at the leaf scale. At the canopy scale, no treatment effects were detected until 37 days after germination. Canopy conductance was significantly greater in the water treatment than in the 2 nitrogen treatments (Fig. 1b). Leaf conductance was significantly greater than canopy conductance in the water and nitrogen-pluswater treatments for corresponding times.

Leaf net photosynthesis decreased with the time from germination $(p=0.00001)$ and was unaffected by treatments $(p=0.42$ [Fig. 2a]). Canopy net photosynthesis was significantly related to the time from germination $(p=0.0001)$. Canopy net photosynthesis was unaffected by treatments or related to the time from germination until the plants were 37 days old (Fig. 2b). At this time, canopy net photosynthesis rates were lower than the earlier observations. Rates of net photosynthesis were lower in the 2 nitrogen treatments than in the water treatment (Fig. 2b). Leaf net photosynthesis was also significantly greater than canopy net photosynthesis in the water and nitrogen-plus-water treatments for corresponding ages.

The ratio of intercellular $\mathrm{ppCO}_{2}$ to ambient $\mathrm{ppCO}_{2}$ was significantly related to the time from germination $(p=0.0004)$, with a significant time-by-treatment interaction ( $p=0.04$ [Fig. 3]). The ratio decreased significantly with the time from germination in the control and water treatments $(b=-0.00408 \pm 0.00114 ; n=$ 10). The ratio in the nitrogen and nitrogen-plus-water treatments decreased from days 6 to 22 , then increased by day 37 . The mean curvature parameter $(e=0.000572 \pm 0.000039 ; n=8)$ was significantly different from 0 . On any day, there were no treatment effects.

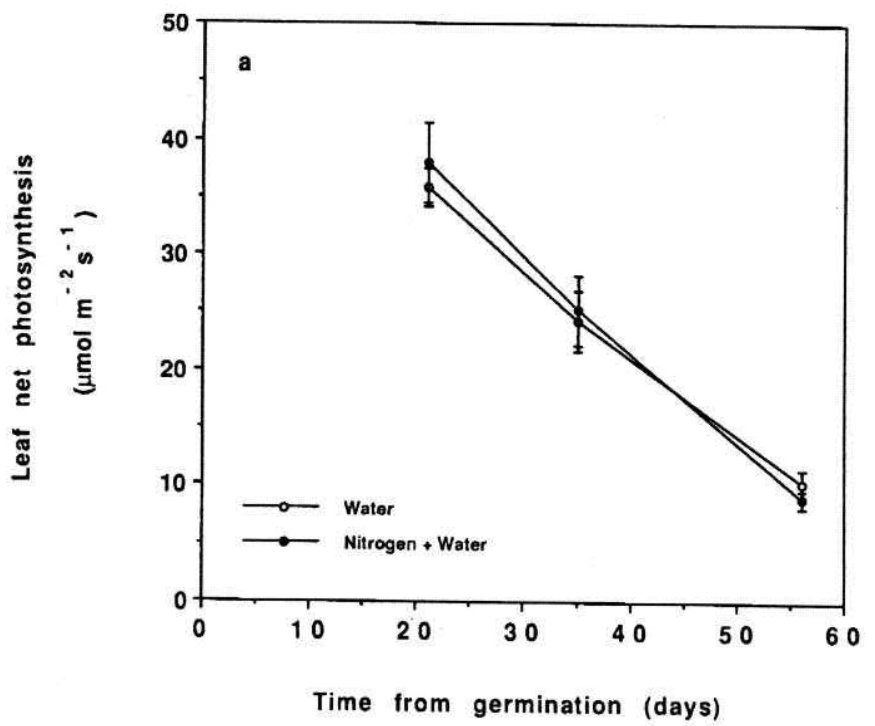

Water-use efficiency, defined as the net photosynthetic rate divided by the transpiration rate, was significantly related to the time from germination $(p=0.0001)$, with a significant time-bytreatment interaction ( $p \leq 0.03$ [Fig. 4]). Water-use efficiency increased significantly with the time from germination in the control and water treatments $(b=0.0631 \pm 0.0181 ; n=10)$. Wateruse efficiency in the nitrogen and nitrogen-plus-water treatments increased from days 6 to 22 , then decreased by day 37. The mean curvature parameter $(e=-0.0112 \pm 0.000695 ; n=10)$ was significantly different from 0 . There were no treatment effects on days 6 or 37 . On day 22 , water-use efficiency was greater in plants in the nitrogen-plus-water treatment than those in the water treatment.

Xylem pressure potentials were not measured on day 6. Xylem pressure potential was significantly related to the time from germination $(p=0.01)$ and treatments $(p \leq 0.03)$ by repeated-measures analysis of variance. Xylem pressure potential decreased for all treatments except the water treatment with the time from germination (Fig. 5). Treatment effects were similar on day 22. On day 37 , xylem pressure potentials in plants in the nitrogen and nitrogen-plus-water treatments were lower than for plants in the water treatment by Duncan's multiple range test. When the same comparisons were made with Tukey's HSD test effects were not significant. This is an indication that the effect of water compared with the nitrogen treatments on xylem pressure potential is test dependent. Because the repeated-measures analysis of variance indicated a significant effect using all the data we conclude that there is an apparent effect of water on xylem pressure potential compared with the nitrogen effects.

Growth as indicated by leaf-area index was significantly related to the time from germination $(p=0.0001)$ and treatments $(p=$ $0.001)$, with a significant time-by-treatment interaction $(p=0.01$ [Fig. 6]). Leaf-area index increased linearly with the time from germination $(p=0.0001)$. Treatment effects were similar on days $6(p=0.9)$ and $22(p=0.08)$, but on day 37, leaf-area index was significantly greater for plants in the nitrogen-plus-water treatment than for plants in the control and water treatments.

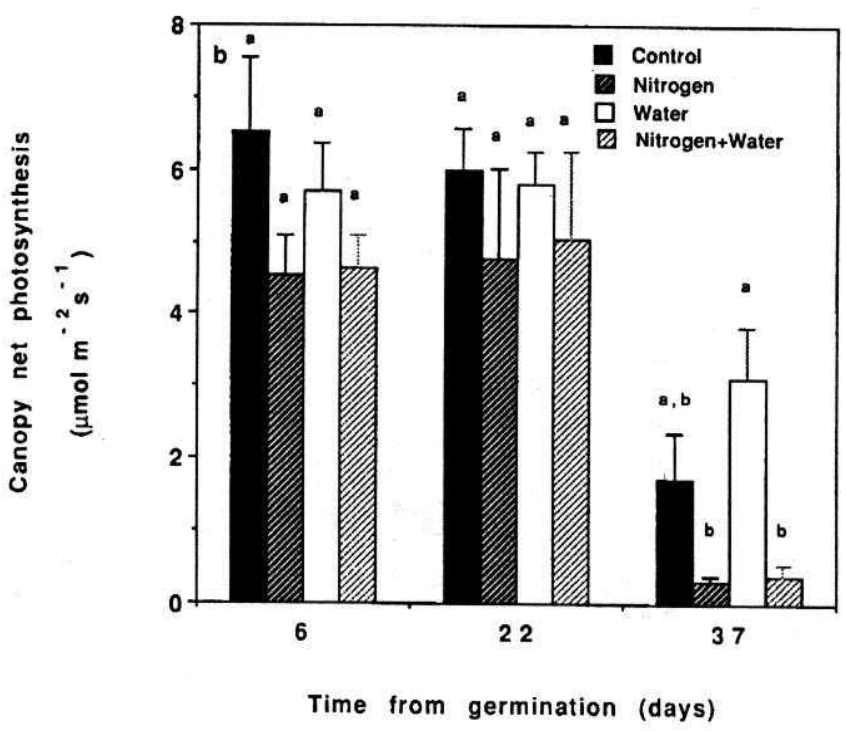

Fig. 2 The effects of the time from germination and water and nitrogen treatments on leaf (a) and canopy (b) net photosynthesis of downy brome. Bars are \pm 1 standard error of the mean. Differing letters indicate significant differences $(P=0.05)$ by Tukey's studentized range test (HSD). 
Table 1. Comparison of mean \pm 1 standard error $(n=5)$ biomass, nitrogen content, and nitrogen-use efficiency of downy brome shoots after 37 days of growth in different treatments. Differing letters indicate significant differences $(P=0.05)$ between treatments by Tukey's studentized range test (HSD).

\begin{tabular}{lccc}
\hline \hline & \multicolumn{3}{c}{ Responses } \\
\cline { 2 - 4 } Treatments & Biomass & Nitrogen & $\begin{array}{c}\text { Nitrogen-use } \\
\text { efficiency }\end{array}$ \\
\hline & $(\mathrm{g})$ & $(\%)$ & $\begin{array}{l}\text { shoot biomass }(\mathrm{g}) \\
\text { shoot } \mathrm{N}(\mathrm{g})\end{array}$ \\
Control & $3.28 \pm 0.43 \mathrm{a}$ & $1.51 \pm 0.07 \mathrm{a}$ & $66.7 \pm 3.1 \mathrm{a}$ \\
Nitrogen & $4.54 \pm 0.17 \mathrm{a}$ & $2.53 \pm 0.22 \mathrm{~b}$ & $40.5 \pm 3.2 \mathrm{~b}$ \\
Water & $3.57 \pm 0.21 \mathrm{a}$ & $1.26 \pm 0.06 \mathrm{a}$ & $80.2 \pm 4.2 \mathrm{a}$ \\
Nitrogen + & $7.36 \pm 0.44 \mathrm{~b}$ & $2.46 \pm 0.29 \mathrm{~b}$ & $42.7 \pm 4.6 \mathrm{~b}$ \\
Water & & & \\
\hline
\end{tabular}

Shoot biomass was significantly greater for the nitrogen-pluswater treatment than for the other 3 treatments (Table 1). Nitrogen fertilization resulted in significantly greater percentage total nitrogen content. Percentage total nitrogen in the nitrogen and nitrogen-plus-water treatments were the same, as was percentage total nitrogen in the control and water treatments. The highest nitrogen-use efficiency values were in the control and water treatments, and the lowest nitrogen-use efficiency values were in the additional nitrogen treatments (Table 1).

\section{Discussion}

Factors related to gas exchange and growth in this experiment were the nitrogen and water treatments, the time from germination, and canopy shading. Gas exchange processes were strongly related to the time from germination and only weakly related to additional water and nitrogen, whereas growth was strongly influenced only by the addition of both nitrogen and water. The effect of the scale of observation was that gas exchange rates were

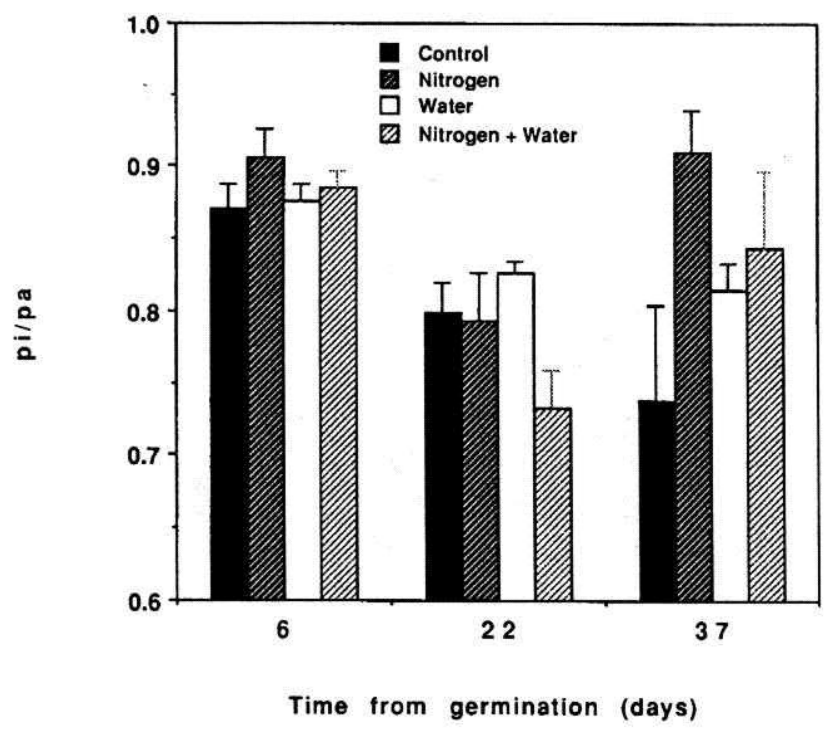

Fig. 3 The effects of the time from germination and water and nitrogen treatments on the internal $\mathrm{CO}_{2}$ ratio (pi/pa) of downy brome. Bars are \pm 1 standard error of the mean.

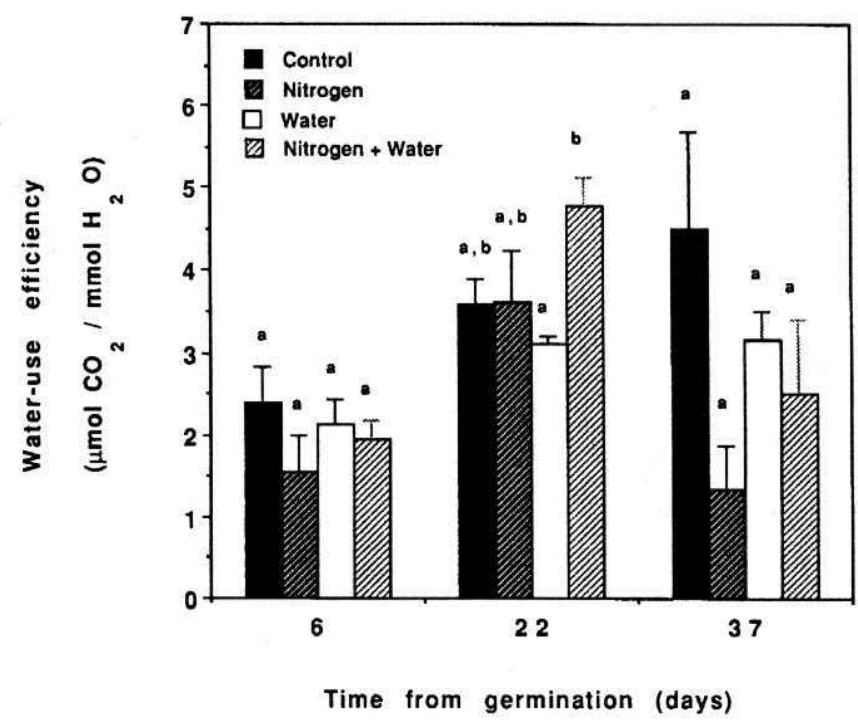

Fig. 4 The effects of the time from germination and water and nitrogen treatments on water-use efficiency of downy brome. Bars are \pm 1 standard error of the mean. Differing letters indicate significant differences $(P=0.05)$ by Tukey's studentized range test (HSD).

greater at the leaf scale than at the canopy scale. This is due in part to differing experimental conditions, but the lower rates at the canopy scale are most likely a result of canopy shading. The finding that growth was strongly influenced by the addition of both water and nitrogen suggests that both are limiting for downy brome under these experimental conditions.

Reductions in stomatal conductance have been observed with plant age (Kramer 1983), water stress, and nitrogen deficiencies (Sheriff 1979, Field 1987, van Keulen et al. 1989). In wellwatered conditions, Evans (1983) found a decrease in stomatal conductance with age, but found that nitrogen had no effect on

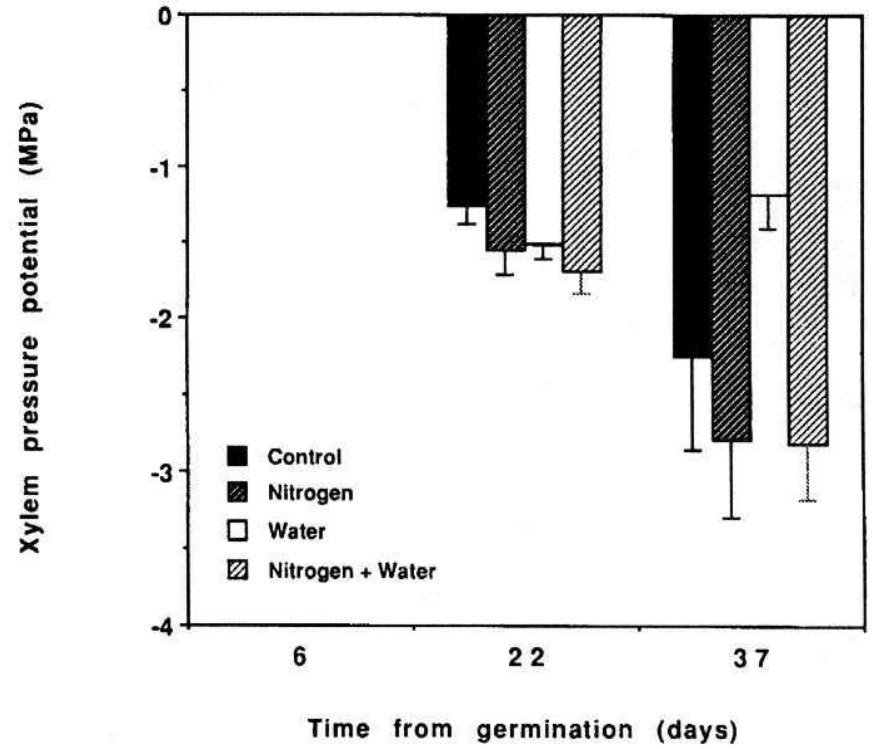

Fig. 5 The effects of the time from germination and water and nitrogen treatments on xylem pressure potential of downy brome. Bars are \pm 1 standard error of the mean. 


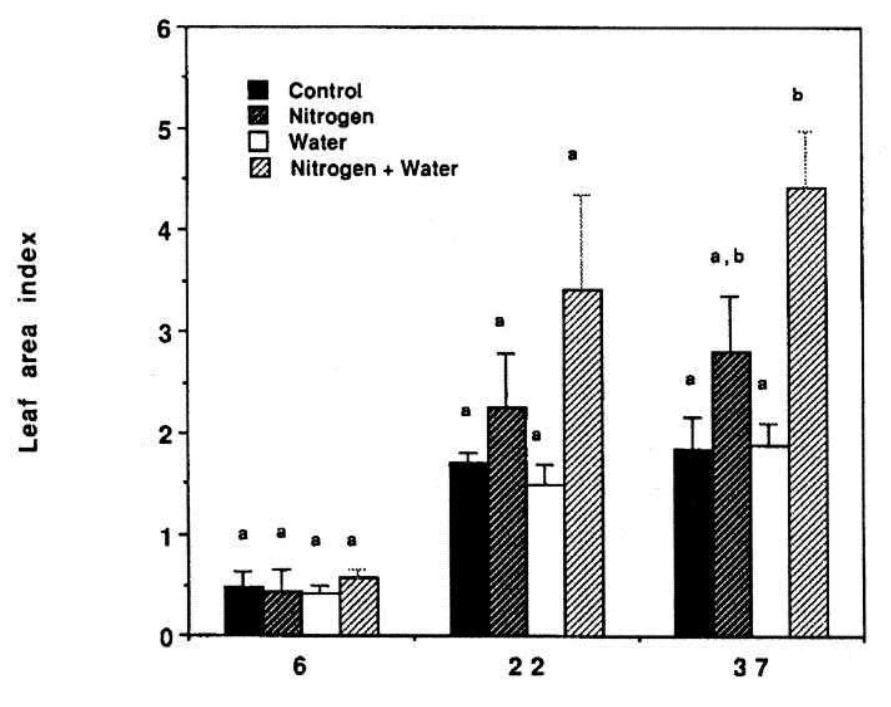

Time from germination (days)

Fig. 6 The effects of the time from germination and water and nitrogen treatments on leaf-area index of downy brome. Bars are \pm 1 standard error of the mean. Differing letters indicate significant differences $(P=0.05)$ by Tukey's studentized range test (HSD).

wheat grown in growth chambers, which agrees with our results at the single leaf scale. Morgan (1988) also found no effect of nitrogen on leaf conductance in field-grown wheat except on 1 day out of 7 over a growing season. Similarly, Toft et al. (1989) found no effect of nitrogen on leaf conductance in 4 cold-desert species. We found no effect of nitrogen on canopy conductance. In contrast, van Keulen et al. (1989) report that there have been many reports of a positive correlation between nitrogen content and stomatal conductance. Because of the variety of responses of stomatal conductance to nitrogen, Van Keulen et al. (1989) conclude that the relationship between nitrogen and transpiration is difficult to predict. The pattern of canopy conductance mirrored that of xylem pressure potential for 37-day-old plants, with plants in the water treatment having the highest canopy conductance and xylem pressure potential. This pattern indicates that water status is a stronger determinant of canopy conductance than nitrogen status. Reductions in stomatal conductance with age may be related to decreased hydraulic conductance to water through the roots, and consequent decreases in xylem pressure potential in downy brome (Link et al. 1990, Downs 1990). The clearest effect of canopy shading on conductance was that rates were about twice as high at the leaf scale as at the canopy scale. We conclude, under these experimental conditions, that the time from germination is the strongest determinant of conductance, followed by canopy shading (at the canopy scale), and plant water status in downy brome.

Net photosynthesis declines with leaf age, as does stomatal conductance (Field 1987, Henson et al. 1990). We observed reductions in net photosynthesis varying with the time from germination, water, and nitrogen status at the canopy scale and varying only with the time from germination at the leaf scale. We found a reduction in canopy net photosynthesis only by day 37 . The reductions in canopy net photosynthesis on day 37 may be related to reductions in photosynthetic capacity due to tissue age and water stress. The pattern of xylem pressure potential mirrors the patterns in canopy net photosynthesis and canopy conductance, suggesting that xylem pressure potential is correlated with canopy net photosynthesis and canopy conductance, at least for 37-day-old plants. Plant age must account for some of the decrease in canopy net photosynthesis, because canopy net photosynthetic rates declined in the water treatment from day 22 to day 37 , while xylem pressure potential increased and the leaf-area index was unchanged.

Changes in net photosynthesis can be interpreted in terms of the changing ratio of intercellular $\mathrm{ppCO}_{2}$ to ambient $\mathrm{ppCO}_{2}$ (Field 1987). On day 22, lowered canopy conductance and relatively high values of canopy net photosynthesis were reflected in decreased ratio values, suggesting that stomatal factors were dominant in limiting net photosynthesis. By day 37 , ratio values continued to decrease in the control and water treatments, but increased in the nitrogen and nitrogen-plus-water treatments. This result suggests that nonstomatal factors are dominant in the nitrogen treatments, and stomatal factors are dominant in the control and water treatments in limiting net photosynthesis (Field 1987). Evans (1983) found an increase in ratio values and a decrease in net photosynthesis in high and low nitrogen treatments in wheat as the plants aged. The effect of the additional nitrogen was to reduce the rate at which net photosynthesis decreased, compared with the low nitrogen treatment (Evans 1983). Leaf nitrogen is reduced as plants age (van Keulen et al. 1989), which may, in part, account for lower net photosynthetic rates on day 37 in the water treatment, as compared to rates on day 22 . We measured leaf nitrogen only at the end of the experiment. We conclude, under these experimental conditions, that the time from germination is a stronger determinant of net photosynthesis than either water or nitrogen status, though the effects of time may merely be manifestations of reduced nitrogen levels.

Field (1987) reviewed the relationship between water-use efficiency and leaf age and found that, in some cases, the ratio of net photosynthesis to stomatal conductance remains constant as leaves age while in others the ratio varies with age. Field (1987) suggests that the lack of an age effect on water-use efficiency means that the stomata establish a consistent compromise between carbon gain and water loss. We found water-use efficiency to be variable with the time from germination in all treatments, suggesting that for downy brome at the canopy scale, stomata do not establish a consistent compromise between carbon gain and water loss.

We observed lower nitrogen-use efficiency in the nitrogen treated plants than in the control and water treatments that agrees with the observation that nitrogen-use efficiency generally decreases with increasing nitrogen content (Vitousek 1982; Lajtha and Klein 1988). A high nitrogen-use efficiency indicates that more biomass has been produced per unit nitrogen (Chapin, III and Van Cleve 1989). Percentage nitrogen, the inverse of 100 nitrogen-use efficiency, was the same in the nitrogen and nitrogen-plus-water treatments. The additional water in the nitrogen-plus-water treatment allowed the plants to grow more, but had no effect on nitrogen concentration.

Biomass responded only to the combination of water and nitrogen, suggesting that both are limiting. Nitrogen limitation to growth has been demonstrated in wheat (Lawlor et al. 1988, Morgan 1988), in other Bromus species (Garnier et al. 1989, Hull and Mooney 1990), and in downy brome (Cline and Rickard 
1973, Rickard 1985). Our observation that nitrogen is limiting agrees with previous studies. In the field, Cline and Rickard (1973) concluded that $71 \%$ of growth could be explained by nitrogen and $12 \%$ by soil water in downy brome. Uresk et al. (1979) found only a weak relationship between soil water and growth rates. We observed that additional water alone had no effect on growth. The effect of additional nitrogen-plus-water on growth was more than could be explained by simple additive effects, implying a synergistic or nonlinear effect on growth. Additional water may facilitate the allocation of carbon to various organs thereby stimulating growth with additional nitrogen (Kramer 1983). Under the conditions of this experiment nitrogen and water were both severely limiting to downy brome shoot biomass production. The addition of both is required to increase shoot production.

While nitrogen is positively correlated with net photosynthetic rates (Field 1987, van Keulen et al. 1989, Hull and Mooney 1990), and biomass, there are exceptions to this association. No strong relationship has been observed between nitrogen applied in the field and net photosynthetic rates of wheat (Gregory et al. 1981, Migus and Hunt 1980, Morgan 1988), even though biomass increased. This was attributed to self shading (Migus and Hunt 1980. Robson and Parsons 1978) that reduces net photosynthetic rates of the additional foliage associated with additional nitrogen (Evans 1983, Morgan 1988). A small gain in photosynthesis was found for nitrogen treatments in canopy studies of Festuca anundinacea (Gastal and Bélanger 1993). They also conclude that self shading limited carbon gain. Additional nitrogen retarded senescence, which Evans (1983) indicated accounted for the difference between nitrogen treatments in that study. Thomas and Thorne (1975) showed that increased carbon gain by flag leaves of wheat high in nitrogen was from increased leaf longevity and larger leaf area, and not from increased photosynthetic capacity. We feel that the addition of water to a high nitrogen treatment facilitates shoot growth, thereby increasing the total carbon gain of the plant, even when net photosynthetic rates are unaffected. Because of the greater leaf-area index in the nitrogenplus-water treatment, the soil water reserve was more rapidly reduced compared with the water treatment, thereby reducing net photosynthetic rates through water stress.

This study has relevance to shaded field conditions. Light levels in this experiment are similar to light levels experienced by $B$. tectorum in forested ecosystems in the Pacific Northwest (Pierson et al. 1990). Pierson et al. (1990) found that B. tectorum plants grown in the shade were smaller, grew slower, and flowered later than plants grown in full sun. Their plants were grown in an unheated greenhouse without water and nitrogen limitation. We did not observe flowering in our experiments which supports the observation that low light delays inflorescence growth. The characteristics of slow growth and late flowering have been observed for numerous grass species grown in the shade (Langer 1979). Pierson et al. (1990) concluded that $B$. tectorum was unsuccessful in shaded forest habitats, in part, because it could not acclimate photosynthetically to low light, had low growth rates and high susceptibility to grazing stress. Our observation of lower shoot biomass with water or nitrogen stress suggests that $B$. tectorum will be even less successful under normal levels of water and nitrogen in forested ecosystems than reported by Pierson et al. (1990).

\section{Conclusion}

Under the conditions of these experiments, downy brome gas exchange processes were strongly related to the time from germination and only weakly related to added water and nitrogen while biomass was strongly influenced only by the addition of both nitrogen and water. Stomatal conductance and net photosynthesis decreased with time. The effect of the scale of observation was that gas exchange rates were greater at the leaf scale than at the canopy scale, with the lower rates most likely a result of canopy shading. Leaf area index and biomass were greater in the nitrogen-plus-water treatment than in the water, nitrogen, and control treatments. The finding that growth was strongly influenced by the addition of both water and nitrogen suggests that both are limiting for downy brome. An examination of the physiological and biochemical responses of $B$. tectorum to additional water and nitrogen will improve our understanding of how $B$. tectortum responds to limiting resources.

\section{Literature Cited}

Billings, W.D. 1990. Bromus tectorum, a biotic cause of ecosystem impoverishment in the Great Basin, p. 301-322. In: G.M. Woodwell (ed.). The earth in transition: patterns and processes of biotic impoverishment. Cambridge Univ. Press, New York, N.Y.

Bloom A.J., H.A. Mooney, O. Bjorkman, and J. Berry. 1980. Materials and methods for carbon dioxide and water exchange analysis. Plant. Cell, and Environ. 3:371-376.

Caemmerer, S. von, and G. D. Farquhar. 1981. Some relationships between the biochemistry of photosynthesis and the gas exchange of leaves. Planta 153:376-387.

Caldwell M.M., J.H. Richards, D.A. Johnson, R.S. Nowak, and R.S. Dzurec. 1981. Coping with herbivory: Photosynthetic capacity and resource allocation in 2 semiarid Agropyron bunchgrasses. Decologia 50:14-24.

Caldwell M.M., T.J. Dean, R.S. Nowak, R.S. Dzurec, and J.H. Richards. 1983. Buncligrass atchitecture, light interception, and water use efficiency: assessment by fiber optic point quadrats and gas exchange. Oecología 59:178-184.

Chapin III F.S., and K. Van Cleve. 1989. Approaches to studying nutrient uptake, use and Joss in plants, p. 185-207. In: R.W. Pearcy, J. Ehleringer, H.A. Mooney, P.W. Rundel (eds.), Plant physiological ecology field methods and instrumentation, Chapman and Hall, New York, N.Y.

Cline J.F., and W.H. Rickard. 1973. Herbage yields in relation to soil water and assimilated nitrogen. J. Range Manage. 26:296-298.

Daubenmire, R. 1970. Steppe vegetation of Washington. Washington Agr. Exp. Sta. Tech. Bull. 62:1-131.

Dixon M., and J. Grace. 1981. Water uptake by some chamber materials. Plant, Cell, and Environ. 5:323-327.

Downs, J.L. 1990. Effects of plant age and soil water deficit on the hydraulic resistance of Bromus tectorum. M.S. Thesis. Washington State Univ., Pullman, Wash.

Evans, J.R. 1983. Nitrogen and photosynthesis in the flag leat of wheat (Triticum aestivum L.). Plant Physiol. 72:297-302.

Field, C.B. 1987. Leaf-age effects on stomatal conductance, p. 367-385. In: E. Zeiger. G.D. Farquhar, I.R. Cowan (eds.), Stomatal function. Stanford Univ. Press, Stanford, Calif.

Field, C.B., J.T. Ball, and J.A. Berry. 1989. Photosynthesis: principles and field techniques, p. 209-255. hr: R.W. Pearcy, J. Ehleringer, H.A. Mooney, P.W. Rundel (eds.), Plant physiological ecology field methods and instrumentation, Chapman and Hall, New York, N.Y.

Garnier, E., G.IV. Koch, J. Roy, and H.A. Mooney. 1989. Responses of wild plants to nitrate availability: Relationships between growth rate and nitrate uptake parameters, a case study with two Bromus species, and a survey. Oecologia 79:542-550. 
Gastal, F., and G. Bélanger. 1993. The effects of nitrogen fertilization and the growing season on photosynthesis of ficld-grown tall fescue (Festuca armdinacea Schreb.) canopies. Ann. Bot. 72:401-408.

Gregory, P.J., B. Marshall, and P.V. Biscoe. 1981. Nutrient relations of winter wheat. 3. Nitrogen uptake, photosynthesis of nag leaves and translocation of nitrogen to grain. J. Agr. Sci. 96:539-597.

Hajek, B.F. 1966. Soil survey, Hanford project in Benton County, Washington. BNIVL-243, Pacific Northwest Laboratory, Richland, Wash.

Henson, I.E., C.R. Jensen, and N.C. Turner. 1990. Influence of leaf age and light environment on the gas exchange of lupins and wheat. Physiologia Plantarum 79:15-22.

Hulbert, L.C. 1955. Ecological studies of Bromus tectorum and other annual bromegrasses. Ecol. Mfonogr. 25:181-213.

Hull, J.C. and H.A. Mooney. 1990. Effects of nitrogen on photosynthesis and growth rates of four California annual grasses. Acta Oecologica $11: 453-468$.

Klemmedson, J.O. and J.G. Smith. 1964. Cheatgrass (Bromus tectornm L.). Bot. Rev. 30:226-262.

Kramer, P.J. 1983. Water relations of plants, Acad. Press, New York, N.Y.

Lajtha, K., and M. Klein. 1988. The effect of varying nitrogen and phosphorus availability on nutrient use by Larrea tridentata, a desert evergreen shrub. Oecologia 75:348-353.

Langer, R.H.M. 1979. How grasses grow, Edward Amold, London.

Lawlor, D.W., F.A. Boyle, A.J. Kcys, A.C. Kendall, and A.T. Young. 1988. Nitrate nutrition and temperature effects on wheat: a synthesis of plant growth and nitrogen uptake in relation to metabolic and physiological processes. J. Exp. Bot. 39:329-343.

Leafe, E. 1972. Micro-environment, carbon dioxide exchange and growth in grass swards, p. 157-174. In: A. Rees, K. Cockshull, D. Hand, R. Hurd (eds.) Crop processes in controlled environments. Acad. Press, London.

Link, S. O., G. W. Gee, and J. L. Downs. 1990. The effect of water stress on phenological and ecophysiological characteristics of cheatgrass and Sandbergs's bluegrass, J. Range Manage. 43:506-513.

Link, S.O., M.E. Thiede, J.L. Downs, D.J. Lettau, and W.J. Waugh. 1992. Evapotranspiration studies for protective barriers: FY 1989 status report. PNL-8033, Pacific Northwest Laboratory, Richland, Wash.

Mack, R.N. 1981. Invasion of Bromus tectorim L. into western North America: an ecological chronical. Agro-Ecosystems 7:154-165.

Migus, W.N., and L.A. Hunt. 1980. Gas exchange rates and nitrogen concentrations in two winter wheat cultivars during the grain filling period. Can. J. Bot. 58:2110-2116.
Morgan, J.A. 1988. Growth and canopy carbon dioxide exchange rate of spring wheat as affected by nitrogen status. Crop Sci. 28:95-100.

Pierson, E.A., R.N. Mack, R.A. Black. 1990. The effect of shading on photosynthesis, growth, and regrowth following defoliation for Bromus tectorlum. Oecologia 84:534-543.

Rickard, W.H. 1985. Shoot production and mineral nutrient assimilation in cheatgrass communities. Northw. Sci. 59:169-179.

Rickard, W.H., and B. E. Vaughan. 1988. Plant communities: Characteristics and responses, p. 109-179. In: W.H. Rickard, L.E. Rogers, B.E. Vaughan. and S.F. Liebetrau (eds.) Shrub-steppe balance and change in a semi-arid terrestrial ecosystem, Elsevier, New York, N.Y.

Robson, M.J., and A.J. Parsons. 1978. Nitrogen deficiency in small closed communities of 524 ryegrass. Photosynthesis, respiration, dry matter production. and partitioning. Ann. Bot. 42:1185-1197.

Scholander, T.F., H.T. Hammel, E.D. Bradstreet, and E.A. Hemmingsen. 1965. Sap pressure in vascular plants. Sci. 148:339-346.

Sheriff, D.W. 1979. Stomatal aperture and the sensing of the environment by guard cells. Plant, Cell, and Environ. 2:15-22.

Stone, W.A., J.M. Thorpe, O.P. Gifford, and D.J. Hoitink. 1983. Climatological summary for the Hanford area. PNL-4622, Pacific Northwest Laboratory. Richland. Wash.

Thomas, S.M., and G.N. Thorne. 1975. Effect of nitrogen fertilizer on photosynthesis and ribulose 1,5-bisphosphate carboxylase activity in spring wheat in the field. J. Exp. Bot. 20:381-400.

Tilman, D. 1986. Nitrogen-limited growth in plants from different successional stages. Ecology 67:555-563.

Tilman, D. 1987. Secondary succession and the pattern of plant dominance along experimental nitrogen gradients. Ecol. Monogr. 57:189-214.

Toft, N.L., J.E. Anderson, and R.S. Nowak. 1989. Water use efficiency and carbon isotope composition of plants in a cold desert environment. Oecologia 80:11-18.

Uresk, D.W., I.F. Cline, and W.H. Rickard. 1979. Growth rates of a cheatgrass community and some associated factors. J. Range Manage. 32:168170

van Keulen, H., J. Goudriaan, and N.G. Seligman. 1989. Modeling the effects of nitrogen on canopy development and crop growth, p 83-105. In: G. Russell, B. Marshall, P.G. Jarvis (eds.) Plant canopies: their growth, form and function. Cambridge Univ. Press, Cambridge.

Vitousek, P. 1982. Nutrient cycling and nutrient use efficiency. Amer. Natur. 119:553-572. 